\title{
IS FUTURE A RULE OF DIGITAL CURRENCY???
}

\author{
Dr. Hariharan Narayanan ${ }^{*} 1 \mathbb{}$ (iD \\ ${ }^{*}$ Founder and Director, Shri Academy, Pune, Maharashtra, India
}

DOI: https://doi.org/10.29121/granthaalayah.v8.i8.2020.935

Article Type: Research Article

Article Citation: Dr. Hariharan Narayanan (2020). IS FUTURE A RULE OF DIGITAL CURRENCY???. International Journal of Research GRANTHAALAYAH, 8(8), 96-106. https://doi.org/10.29121/granthaa layah.v8.i8.2020.935

Received Date: 01 August 2020

Accepted Date: 24 August 2020

Keywords:

Digital Currency

E-Money

Cryptocurrency

Virtual Currency

Fiat Currency

Bitcoin

\begin{abstract}
Digital Currency (DC) is a form of currency that is available in digital or electronic form and not in physical form. Digitalization has remodeled money and payments systems. Although digital money itself is not new to modern economies, digital currencies now facilitate spontaneous peer-topeer transfers of value in a way that was formerly impossible. Digital currency has already materialized in a variety of contexts. Digital Currency is an extent put away in a dispersed database on the Internet. This study is toted with the objective to highlight the concept of digital currency, its various forms, evolution and growth, global impact, impact during COVID19 and the future of digital currency. This is an historical descriptive study which flashes the opinions given by distinctive researchers and disparate financial consultants and central banks.
\end{abstract}

\section{INTRODUCTION}

Money is a financial instrument which act as a mode of exchange, unit of record, store of significant worth and standard of deferred payment. In the monetary system the firms and individuals lean to relate paper notes and coins issued by central bank as cash which is termed as money. The scope of money does not stop here. Slowly automation and digitalization cropped and took the lead as instrument for exchange of goods and services which gave way for the birth of Digital Currencies (DC). DC are those which do not have physical type of banknotes and coins yet which are digital or electronic. It is also called as Digital Money, Electronic Money, Electronic Currency or Cyber Cash. DC are accessible only through internet via computers or mobile phones since they are in electronic from. They are intangible in nature. DC cannot be defined in general. The definition and meaning depends on the distinct legal and contextual properties within any limited jurisdiction and thus the distinct agencies and regulators define differently on the properties of a specific DC. These currencies may be used to buy physical goods and services. DC have all intrinsic properties ${ }^{1}$ like physical currency, and they allow for spontaneous transactions that can be flawlessly executed for making payments across borders when associated with upheld gadgets and networks. The main

\footnotetext{
1 https://www.investopedia.com/terms/d/digital-currency.asp

(C) 2020 The Author(s). This is an open access article distributed under the terms of the Creative Commons Attribution License, which permits unrestricted use, distribution, and reproduction in any medium, provided the original author and source are credited. 
benefits associated with DC are easy and timely payments and low transaction costs. Security, currency volatility and payment beneficiary identification are the main risks which are associated to DC. In the present era DC are the least expensive technique to trade currencies. The main purpose of this study is to bring awareness about the concept of "Digital Currency", its various form, evolution and growth, global adoptability and the impact of DC during this COVID-19 pandemic era with a highlight about "Future of DC". In this era for each and everything it is Digital. Especially during this COVID-19 - Humans cannot meet But Transactions can Meet with Digital Currency. Hence the researcher felt this study will bring an importance in this period.

\section{OBJECTIVES}

- To study the growth and emergence of Digital Currency

- To study the concept and various forms of Digital Currency

- To study the adoptability of Digital Currency

- To study the impact of Digital Currency during COVID-19 Pandemic

- To study the future of Digital Currency

\section{MATERIALS AND METHODS}

This study is Historical, Descriptive and Analytical in nature. Materials are collected from Secondary Sources. The sources incorporate working papers published by various central banks, financial organizations, bank institutes and financial consulting firms. Any biased data on the secondary source may reflect on the study, which will be a limitation.

\section{DISCUSSION AND RESULTS}

This discussion and results deal with the concept of Digital Currency, various forms of digital currencies, emergence and growth of DC, global adaptability and its impact, DC impact during COVID-19 and finally followed by the Future of DC. To make it more user friendly for the readers the discussions are separated into four segments:

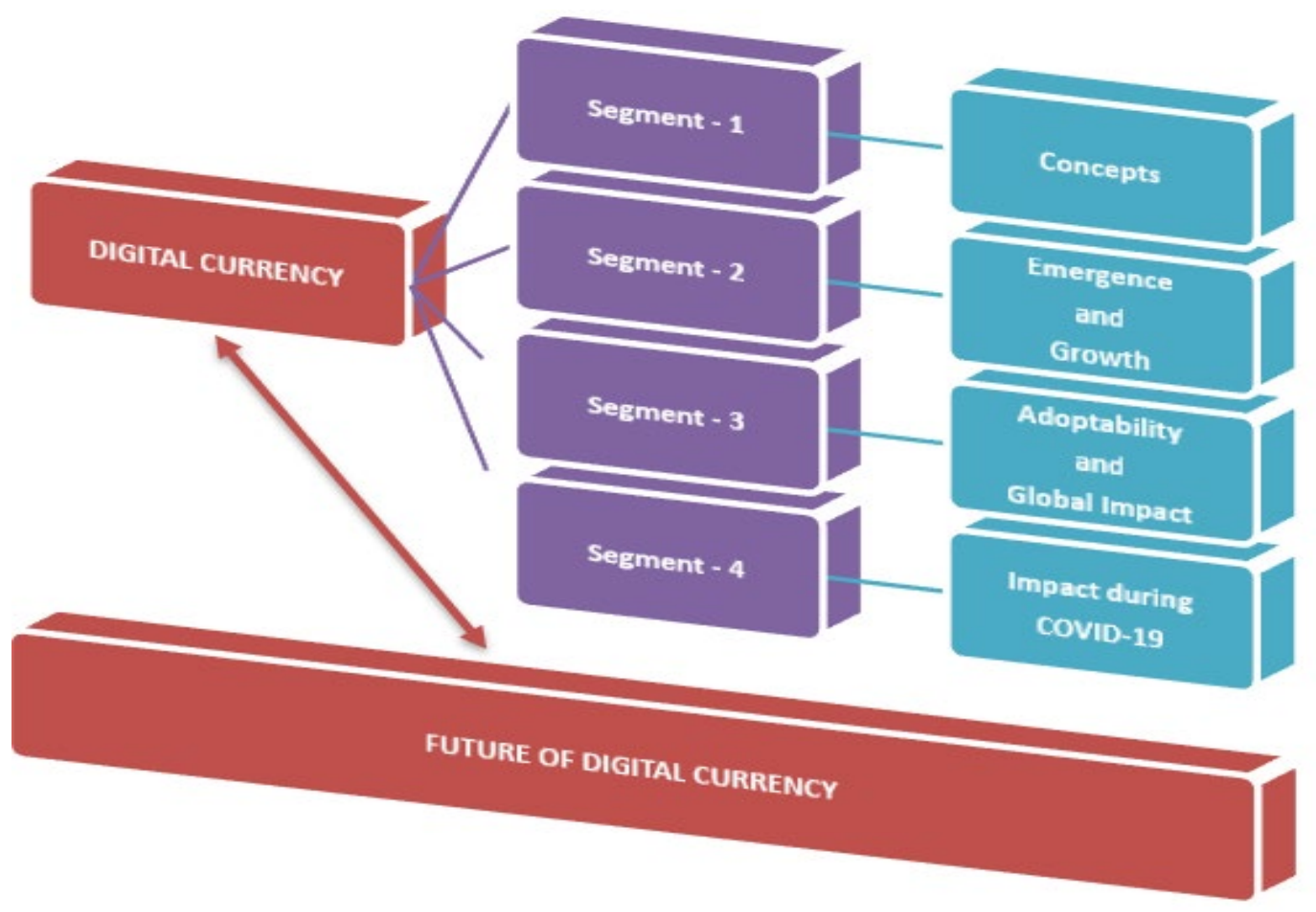

Source: Compiled by Author

Figure 1 


\subsection{CONCEPTS AND VARIOUS FORMS OF DIGITAL CURRENCY / DIGITAL TOKENS}

\section{Digital Currency}

(Rose, 2015) It is a form of virtual currency that is electronically created and stored. Except few not all digital currencies are cryptocurrencies. (Morabito, 2017) $\mathrm{DC}^{2}$ do have some, but not all the characteristics of a currency. They may also have the characteristics of a commodity or other asset. Their legal treatment can vary from jurisdiction to jurisdiction. DC and especially those which have an embedded decentralized payment mechanism based on the use of a distributed ledger ${ }^{3}$ (decentralized payment mechanism), are an innovation that could have a range of impacts on various aspects of financial markets and the wider economy. (Wadsworth, 2018) A generous term that captures all forms of money that are not physical.

Table 1: Examples of Digital Currencies ${ }^{4}$

\begin{tabular}{|c|c|c|c|c|}
\hline Bitcoin & Litecoin & Dash & Renminbi & Monero \\
\hline Dogecoin & Bitcoin Cash & VEN & NEM & NXT \\
\hline Titcoin & Chinacoin & Microsoft Points & Ethereum & Ripple \\
\hline Primecoin & Peercoin Ven & Steller Lumens & Ethereum Classic & Zcash \\
\hline Namecoin & Auroracoin & IOTA & TRON & Cardano \\
\hline Gridcoin & Mazacoin & EOS & NEO & Verge \\
\hline Potcoin & Vertcoin & Nano & Tether & Onecoin \\
\hline
\end{tabular}

Source: Compiled by Author from Various sources

\section{Virtual Currency}

(Peters et al., 2015) These currencies are claimed as the medium of exchange in an online virtual economy and they have sameness with their fiat currency counterparts. They are more prevalent in online games or life simulate games. Participants use this currency for the purchase of virtual goods and services. Virtual currencies cannot be fully treated as e-Money since, because although they share some of its attributes, there is currently no legal authorizing to enforce the link between fiat physical money and virtual currencies. (Lim, 2015) Defined as a "digital representation of value that can be digitally traded and function as (a) a medium of exchange and/or, (b) a unit of account and/or (c) a store of value but does not have legal tender status in any jurisdiction. They are not issued as such and are instead created following to, and governed by, private agreement among a community or users and other network participants. (Rose, 2015) In 2012 the European Central Bank defined a virtual currency as a "type of unregulated, digital money, which is issued and controlled by its developers and accepted among the members of a particular implicit community". The US Department of Treasury states that although a digital currency operates just like a traditional currency, it does not have the same attributes.

\section{Stable Coins}

(Maire et al., 2019) A new category of virtual currency that have gained attention. They are not strictly cryptocurrencies, despite using a digital token and they have very different monetary underpinnings and issuance administrations. Stable coins come in three varieties: i) one-to-one equivalent amount of official fiat currencies; ii) backed by financial assets and not by fiat currencies and iii) issuance regulated by a sophisticated algorithm.

\section{Cryptocurrency}

It is a member of virtual currencies. Cryptocurrencies are interchanged via consumer sentiment and psychological prompt in price movement. All crypto currencies are digital currencies and not all digital currencies are crypto currencies. They are supported by Distributed Ledger Technology (DLT) in which secure registers are permanently synchronized between a large number of participants.

(Lim, 2015) Cryptocurrencies are decentralized. It is issued without a central administering authority. They are also defined as "convertible virtual currencies", which means they have an equivalent value in real fiat currency and

\footnotetext{
2 https://www.bis.org/

${ }^{3}$ Based on CPMI report on Digital Currencies (Committee on Payments and Market Infrastructures)

${ }^{4}$ It includes those which are in existence and those which are not in existence also. 
can also be exchanged for such fiat currency. This type of currency functions both as currency as well as a peer-topeer payment platform. (Nian \& Chuen, 2015) Cryptocurrency in its realest form is a peer-to-peer version of electronic cash. It licenses online payments legitimately from one party to the other without any intermediary. Transactions have cryptographic proof of work. Cryptocurrency was thought to possess the characteristics of a currency that can institute fiscal discipline on the government and it is sensed to be a debt-free currency with a constant growth rate with finite supply. Following are considered as the main arguments for the success of Cryptocurrency:

- Open-source software

- Decentralized

- Peer-to-peer

- Global

- Fast

- Reliability

- Secure

- Sophisticated and flexible

- Automated

- Scalable and

- Platform for integration

(Wadsworth, 2018) A digital currency that requires distributed ledger technology and encryption techniques to be transferred. (Maire et al., 2019) Cryptocurrencies can be described as an artful combination of Technological, Monetary and Design innovation methods. Cryptocurrencies make extensive use of age-old mechanics that have been improved over time. They look identical to existing electronic money or e-money but they are distinct. They are not related to bank account and not a claim on any natural or legal entity. They are designed to function expertly on an open network with no expectation between participants and dispense with any financial intermediary.

\section{Altcoin \\ (Wadsworth, 2018) Collective term referring to crypto-currencies other than Bitcoin}

\section{Non-Convertible virtual currencies}

(Lim, 2015) It is related to a particular domain or virtual world under particular rules governing their use and cannot be exchanged for fiat currency

\section{Hard Vs Soft Digital Currencies}

Any currency for which the payment cannot be reversed once used is termed as hard currency. It is similar to cash. Whereas if payments can be reversed it is soft electronic or digital currency.

\section{Fiat Currency}

Fiat currency is a money established by the Government. It is a government-issued currency which has no intrinsic value. It is a "National Currency" issued by a country's government or central bank. Any paper currency and coins released by the Central bank of a particular country constitutes "Fiat Currency". All currencies issued by the Central Bank of respective countries are Fiat Currency of that particular country. (Wadsworth, 2018) Central banks issue fiat currency (Cash) on behalf of governments. Fiat currency is physical currency and legal tender ${ }^{5}$. People count on fiat currency to the degree that they trust that the government will not go bankrupt and that the national economy will not slump. People use fiat currency because it is a good unit of account, medium of exchange and store of value and because it can be used to pay taxes ${ }^{6}$. (Wadsworth, 2018) Physical forms of money that - i) a government issues and declares to be legal tender and ii) is not backed by a promise of convertibility into a tangible asset such a gold.

\footnotetext{
${ }^{5}$ If money is a legal tender this means it is legally recognized as a valid form of payment and represents a claim.

${ }^{6}$ The Chartalist theory of money describes that money derives its value from trust that the government that issued the money will not or cannot go bankrupt. 


\section{Bitcoin}

(Lim, 2015) It was introduced in 2009. It is a type of cryptocurrency which is adopted worldwide for commercial and business application to real-world goods and services. Bitcoin are not released or backed by any government or central bank and their value does not evolve from precious metals or other similarly tangible intermediaries of value. They are intangible in nature, exists only digital and have no intrinsic value. (Nian \& Chuen, 2015) Bitcoin is a decentralized network and a digital currency that uses a peer-to-peer system to verify and process transactions. Bitcoin technology uses cryptographic evidence in its computer software to process transactions and to authenticate the validity of Bitcoins and spreads the processing work among the network. Payments can be made over the Internet without the control and costs of a central authority. The currency unit used in payments on the Bitcoin network is Bitcoins and not a fiat currency. (Glass, 2017) Mining is the handle by which Bitcoins entered into the Bitcoin ecosystem. Bitcoins are the universally used digital currency. Till date there is no one who is specifically been credited for inventing the Bitcoin ecosystem, Satoshi Nakamoto ${ }^{7}$ - the person who published the initial conceptual and technical description of Bitcoin in 2008 - is credited as the digital currency's intellectual father. (Wadsworth, 2018) A crypto-currency that uses Blockchain and proof-of-work validations. Several competing Bitcoin currencies each have Bitcoin in their own names.

\section{E-MONEY}

(Peters et al., 2015) Electronic Money (e-Money) refers to the monetary value which is stored electronically, represented by a claim and issued on receipt of funds for making payment transactions by an issuer. This will be accepted by any person who is not the eMoney issuer. It includes prepaid cards and electronic prepaid accounts used online. Typically e-Money is stored in the same unit of account as the fiat denomination use to obtain the e-Money. (Tobias Adrian, 2019) eMoney8 is a means of payment and a store of value fully backed by fiat currency. It is the digital equivalent of a pre-paid card. eMoney includes a version of "Stable coins" that is fully backed by fiat currency - what some call as "Digital Fiat Currency". eMoney can be traded through an app on your cellphone, between individuals and business alike with ease and immediate effect.

\section{Blockchain}

(Wadsworth, 2018) A distributed, open source, public and permissionless ledger. It is titled the Blockchain as the ledger consist of a chain of completed blocks of transactions. (Ward \& Rochemont, 2019) Blockchain enables multiple users to make entries into a record of information and a community of users can control how the record of information is amended and updated. As such, every node in the network receives the same information and each node updates the record independently. This thereby eliminates the need for a trusted party to facilitate digital relationships. It is on Blockchain technology that DC have evolved. The key concepts of Blockchain terminology are tokens and smart contracts.

\subsection{DIGITAL CURRENCY - EMERGENCE AND GROWTH - GLOBAL SKETCH}

Table 2

\begin{tabular}{|c|c|c|}
\hline $\begin{array}{c}\text { S. } \\
\text { No. }\end{array}$ & Year & Emergence and Growth \\
\hline 1 & $1960 \mathrm{~s}$ & Existence of Electronic Fund Transfer - EFT \\
\hline 2 & 1980 & $\begin{array}{r}\text { Development of Network Technology and electronic payments became more useful with the } \\
\text { appearance of credit and debit cards. }\end{array}$ \\
\hline 3 & 1983 & David Chaum, introduced the idea of Digital Cash \\
\hline 4 & 1990 & David Chaum, Amsterdam, Followed DigiCash \\
\hline 5 & 1990 & Emergence of Virtual Currency \\
\hline 6 & 1996 & e-Gold - Wisely used Internet Money \\
\hline 7 & 2008 & Satoshi Nakamoto is credited as the DC "Intellectual Father" \\
\hline
\end{tabular}

\footnotetext{
${ }^{7}$ https://www.coindesk.com/learn/blockchain-101/why-use-a-blockchain

${ }^{8}$ https://www.imf.org/en/News/Articles/2019/05/13/sp051419-stablecoins-central-bank-digital-currencies-and-crossborder-payments (Remarks by Tobias Adrian at the IMF-Swiss National Bank Conference, Zurich, May 2019) 
Is Future A Rule of Digital Currency???

\begin{tabular}{|c|c|c|}
\hline 8 & 2009 & Bitcoin was introduced and created a world first decentralized alternative currency \\
\hline 9 & From & Immense growth of Digital Currency Globally in various forms \\
& 2010 & \\
\hline
\end{tabular}

Source: Compiled by Author from various secondary sources

\subsection{GLOBAL ADOPTABILITY AND IMPACT OF DIGITAL CURRENCY}

(Accenture Research, 2017) Central Bank and Cryptocurrency: The study published by "Accenture consulting" have highlighted the benefit, impact and challenges of cryptocurrencies under three major headings as discussed below:

Cryptocurrencies Benefit for Market Participants include:

- Immediate asset availability

- Immediate approach to liquidity

- Free up working capital

- Transaction efficiency

- Transaction security

Impact on the economy because:

- Boost economic growth

- Act as an enabler for mobile and digital commerce

- Ensure balance in the financial system

- Work as a crypto-reserve currency

- Productively monitor the supply of money

- Lower costs

- Allow for traceability

Challenges for Central Bank when deploying cryptocurrency are:

- To establish a governance structure

- To give policy direction

- To regulate the economy

- To provide legal backing

(Dabrowski \& Janikowski, 2018) Virtual currencies (VCs) are a contemporary form of private money. The transactions of VCs are relatively safe, transparent and fast. VCs are used globally, disregarding national borders. In April 2018, there were more than 1,500 VCs out of which only few currencies had market turnover and capitalization. Bitcoin remains a leader among them. (Khiaonarong \& Humphrey, 2019) Central Bank Digital Currency (CBDC) Studies in Selected Countries ${ }^{9}$ are: - Canada: The Bank of Canada has provided analytical work on digital cash to explore the use of representations of the Canadian dollar (called Digital Depository Receipt) for making payments. The Bank of Canada, Bank of England, and the Monetary Authority of Singapore have also contributed to examiner the future models of cross-border interbank payments and settlements. China: The People's Bank of China established the Institute of Digital Money in 2017 and has published a systematic framework to understand CBDC. The institute is investigating a set of new and reportedly superior payment features, compared to existing privately issued digital cash, the specifics of which have not been disclosed. Denmark: Danmarks National Bank have provided analytical work on the merits and demerits of a CBDC in DK. National bank finds that in the Danish case the risks connected with issuing CBDC out weight the possible benefits for society. Norway: A decision to issue CBDC would be based on a socio-economic cost-benefit analysis. The central bank will continue to issue cash if there is a demand for it. If usage declines to very low levels, digital cash could be a substitute to deposit money to ensure confidence in cash and the monetary system. If issues, digital cash should be structured to avoid impairing the ability of banks and other financial institutions to provide credit. Singapore: Project Ubin experimented using digital representations of the Singapore dollar for making domestic interbank payments. It was extended to delivery versus payments against tokenized assets and include cross-border payments. Sweden: Only planning to assess the technical features of digital cash, legal issues and the impact towards central bank's monetary policy were made and no decision on CBDC

${ }^{9}$ https://www.imf.org/en/Publications/WP/Issues/2019/03/01/Cash-Use-Across-Countries-and-the-Demand-for-CentralBank-Digital-Currency-46617 (From IMF working papers.) 
was drafted. By functioning independently from the infrastructure used by the commercial bank system, the e-krona would be targeted for smaller payments and serve as a direct claim on the central bank. It would not pay any interest on central bank deposits initially and offer off-line payment features for groups that do not desire or are ineligible for e-krona accounts. United Kingdom: The Bank of England has explored the macroeconomic impact of central bank issued digital currencies, and their principle map and balance sheet implications.

\subsection{IMPACT OF DIGITAL CURRENCY IN COVID-19}

(Auer et al., 2020) The COVID-19 pandemic has led to unprecedented public concerns about viral transmission via cash. Central banks report a large increase in queries from the media on the safety of using cash. The number of internet searches pertaining to both "cash" and "virus" is at record highs. Overall, Australia, France, Singapore, Switzerland, Ireland, the UK, Canada, the USA, Jamaica and Kenya have had the highest recent search interest. There are vast cross-country differences regarding this. Scientists felt that the probability of transmission via banknotes is low when compared with other frequently touched objects. The head of the German public health institute notes that "Viral Transmission" through banknotes has no particular significance. Moreover, experts voice that sanitizing hands after touching cash or other objects may help in reducing the risk. Cash circulation in USA has recently increased whereas in UK, automated teller machine (ATM) withdrawals have fallen. Current development brings Digital Payment to the Fore. Contactless card payments methods in several countries have increased and in countries like Austria, Germany, Hungary, Ireland, the Netherlands, the United Kingdom the transaction limits were increased so that physical contacts are reduced. Digital Wallets and smartphone-based payments are the core methods which are followed. (Accenture Research, 2020) This published paper by Accenture has given ten impacts of COVID-19 on the payments industry which are likely to influence payment providers' actions today and tomorrow:

Table 3

\begin{tabular}{|c|c|}
\hline \multicolumn{2}{|c|}{ IMPACT OF COVID-19 ON PAYMENTS } \\
\hline 1 & Key payments markets are the most affected by COVID-19 \\
\hline 2 & Consumer spending has slowed, which has impact towards payment revenue streams \\
\hline 3 & Payments providers are shooting initiatives to withhold economic liquidity \\
\hline 4 & Restricted revenues have made payment companies to rethink towards short-term priorities \\
\hline 5 & Even though cash withdrawals increased in the beginning, it has gradually declined in the course of time \\
\hline 6 & Tokenized payments are being supported more \\
\hline 7 & Fraud has more positive role in this circumstances \\
\hline 8 & "Embedded" payment experiences are likely to become more popular \\
\hline 9 & Consumers and businesses are likely to be drawn to payment experience that offer more control \\
\hline 10 & Viable payments use cases for blockchain may be uncovered \\
\hline \multicolumn{2}{|c|}{ Source: https://www.accenture.com/sa-en/insights/banking/coronavirus-ten-impacts-payments } \\
\hline
\end{tabular}

(Leadership, n.d.) Since Bitcoin became a phenomenon outside the technology world, cryptocurrencies have been a matter of study for central banks. In these moments of geopolitical instability and tensions in currency markets, there could be a push to IMF or national government sponsored digital currencies. Since these currencies would be centralized, Bitcoin and other public Distributed Ledger Technologies - DLTs would not be strictly necessary. Private, centralized, permissioned DLTs could be used. Such move can be accompanied by a big push towards totally cashless societies, for different reasons - specially health and sustainability. (Deutsche Bank Research, 2020) Looking towards the medium- and long-term concerns over handling cash, central banks will look into the development of own Digital Currencies (CBDCs). Over the past two years, global central banks have increased their digital cash initiatives. Today, 80 percent of them are developing a CBDC and the work goes far beyond research. In February 2020, Sweden, a country where cash in circulation now represents only one percent of GDP, revealed that it began its first trial of the e-krona and is expected to become the world's first cashless society by March 2023. USA Federal Reserve could use a "Digital Dollar" and digital wallets to send payments to individuals and businesses. Looking ahead, countries representing about a fifth of the world's population are likely to issue a 
Is Future A Rule of Digital Currency???

general purpose CBDC in the next three years ${ }^{10}$. Without any formal announcement, China began trialing payments - with Starbucks and McDonalds on-board - in its new digital currency.

......As Bill Gates has previously warned, it may have coincidently emerged when we have the ability to respond (at least to the cash problem) with a once-in-a-century solution......

The virus has already driven nations to disinfect, destroy, and reprint their currencies. Compared with that, a digital payment system must seem a far more straightforward solution.

\section{FUTURE OF DIGITAL CURRENCY}

("The Future of Money," 2011) The growth of digital economy has already impacted industries as diverse as media, music and transportation. It's a development that will increasingly obscure the distinction between money and data. Controllers, governments and organizations have a lot to pick up as the web of cash gets going. The open doors are boundless, yet the hindrances to making, overseeing and managing a multiplying cluster of computerized types of cash are generous. (Accenture Research, 2017) Fear of Cryptocurrencies wrest some control away from central banks and traditional financial players and disrupt the market is always there. While blockchain engaged advanced monetary forms are a long way from develop, their interruption of the current money related framework is unavoidable. Cryptographic forms of money are making a cash transformation. Accenture believes that central banks have the exclusive power needed to bring together all financial players in the market to establish a heavy foundation for cryptocurrencies. (Lagarde, 2018) Advanced stages are reshaping the connections between clients, laborers and bosses as the silicon chip's range pervades nearly everything, we do from purchasing food supplies online to finding an accomplice on a dating site. In the meantime, mysterious digital forms of money, for example, Bitcoin are presenting difficulties to endeavors to battle tax evasion and other unlawful exercises. Digitalization will likewise change individuals' employments. The occupations of up to 33\% of the US workforce, or around 50 million individuals, could be changed by 2020, appropriately to a report distributed by McKinsey Global Institute. Advanced innovation will spread further, and endeavors to overlook it or administer against it will probably fall flat. The computerized transformation ought to be acknowledged and improved as opposed to overlooked and stifled. Instruction and rivalry strategy will likewise be adjusted. Schools and colleges ought to give coming ages the abilities they have to work in the developing economy. (Boshkov, 2019) Bitcoin and other cryptocurrencies can take over the traditional payment systems. To achieve this success they should provide an individual value, overcome challenges and should meet regulatory frameworks. Cash has not yet been replaced by any form of electronic payment till date. (Sibilia, 2019) The main economic insight is digital currencies will unbundle the functions served by money, rendering the competition among currencies much fiercer and digital money issues will try to "product differentiate" their currency by re-bundling monetary functions with traditionally separate functions, such as data gathering and social networking services. The significance of advanced connectedness, which frequently overrides the significance of macroeconomic connections, will prompt the foundation of "Computerized Currency Areas" (DCAs) connecting the money to usership of a specific computerized arrange as opposed to a particular nation. (Perkins, 2020) Cryptocurrencies since 2008 invention have escalated. Lately, they encountered a fast increment and resulting decline in value. One estimate found that, as of March 2020, there were more than 5,100 different cryptocurrencies worth about $\$ 231$ billion, has drawn the attention of the public and policymakers.

Table 4: Countries which will be Cashless Leaders by $2022^{11}$

\begin{tabular}{|c|c|}
\hline S. No & Country Name \\
\hline 1 & Finland \\
\hline 2 & Sweden \\
\hline 3 & China \\
\hline 4 & South Korea \\
\hline 5 & United Kingdom \\
\hline 6 & Australia \\
\hline
\end{tabular}

Source: Secondary Source - Globaldata.com

${ }^{10} \mathrm{https} / /$ www.bis.org/publ/bppdf/bispap107.pdf

${ }^{11}$ https://www.globaldata.com/top-countries-moving-towards-a-cashless-society-by-2022/ International Journal of Research -GRANTHAALAYAH 


\section{CONCLUSION}

Exchange over the network has expanded the utilization of new advances, along these lines expanding the interest for new electronic installment strategies. Yet the ambiguities encompassing the utilization of the advanced cash leave area for investigation of its open acknowledgment, trust and expectation, which are the primary driver for the spread of the orderliness. The money related industry is seeing advances in budgetary innovation and expanding customer inclinations towards online monetary administrations. In this condition, national banks are thinking about their job as guarantors of money. The continuous computerized transformation and the ascent of enormous tech firms present the chance of an extreme lift from the traditionally model of money related trade. History and development analyzed in the sequential order in this study, obviously makes it visible that Bitcoin and different digital forms of money are improving with noticeable quality. Digital currency can't demonstrate its prosperity without anyone else except if the central banks approaches to dispatch the equivalent. Another point not to miss is that "cryptographic money" is as yet developing and there is no specific answer for the same.

\section{AUTHOR'S SENSATION}

Knowingly or Unknowingly all are inclined to e-Money in this era throughout Universe. How, When, Where and By Whom are all a BIG ??????????????????

It has its answer by itself and consequently things are moving day-by-day unknowingly. Technology and Digitalization has transformed over a period of time and now we are in the chapter of "Everything through Digitalization". All interchanges and connections, business and exchange, education and learning, are through digitalization and for this PAYMENT and RECEIPT of money/cash is through Online digitalization which brings and features the significance of Digital Currency. If Digital money are controlled and given a reinforcement by the central bank FUTURE WILL BE DIGITAL CURRENCY and it will not be a surprise even if machine itself choose and decides about Whom to pay? How much to Pay? When to Pay? and also How to Pay?

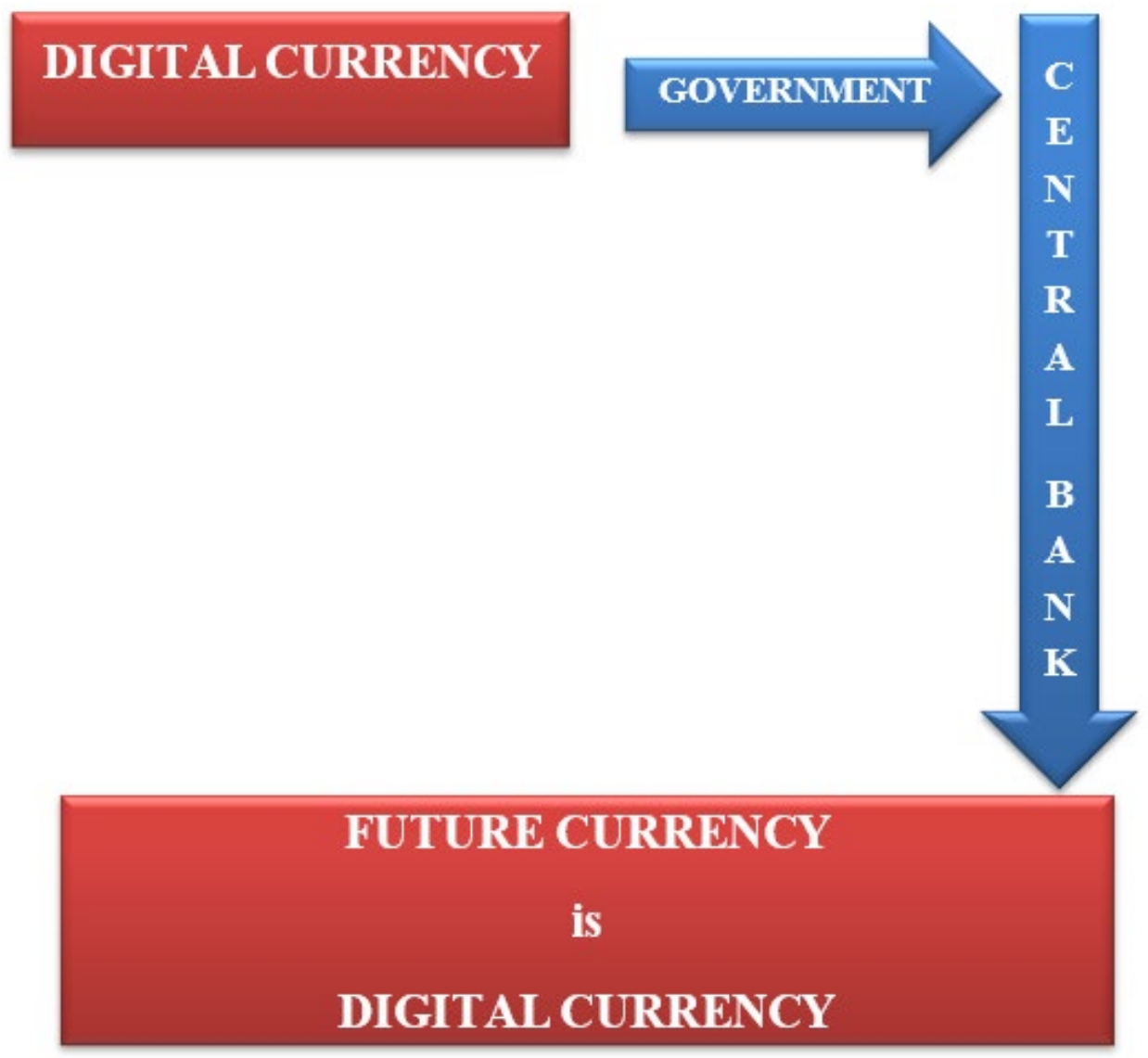


Is Future A Rule of Digital Currency???

\section{SOURCES OF FUNDING}

This research received no specific grant from any funding agency in the public, commercial, or not-for-profit sectors.

\section{CONFLICT OF INTEREST}

The author have declared that no competing interests exist.

\section{ACKNOWLEDGMENT}

None.

\section{REFERENCES}

[1] Accenture Research. (2017). The (R)evolution of Money | Accenture. https://www.accenture.com/t20171116T025715Z_w_/us-en/_acnmedia/PDF-63/Accenture-EvolutionMoney-Blockchain-Digital-Currencies.pdf

[2] Accenture Research. (2020). 10 Ways COVID-19 is Impacting Payments | Accenture. https://www.accenture.com/sa-en/insights/banking/coronavirus-ten-impacts-payments

[3] Auer, R., Cornelli, G., \& Frost, J. (2020). COVID-19, cash, and the future of payments. BIS Bulletin, 3, 3. https://www.bis.org/publ/bisbull03.htm

[4] Boshkov, T. (2019). Blockchain and Digital Currency in the World of Finance. Intech, 19. https://doi.org/10.5772/intechopen.79456

[5] Dabrowski, M., \& Janikowski, L. (2018). Virtual Currencies and Their Potential Impact on Financial Markets and Monetary Policy. In SSRN Electronic Journal (Vol. 495, Issue 495). https://doi.org/10.2139/ssrn.3244429

[6] Deutsche Bank Research. (2020). Life after COVID-19. https://www.bis.org/publ/bppdf/bispap107.pdf

[7] Glass, J. E. (2017). What is Digital Currency? IDEA - The Journal of the Franklin Pierce Center for Intellectual Property, 57(3), 455-517.

[8] Khiaonarong, T., \& Humphrey, D. (2019). Cash Use Across Countries and the Demand for Central Bank Digital Currency IMF Working Paper Monetary and Capital Markets Department Cash Use Across Countries and the Demand for Central Bank Digital Currency. March.

[9] Lagarde, C. (2018). A regulatory approach to fintech; Point of View: Going Cashless; Monetary Policy in the Digital Age. In IMF Finance \& Development (Vol. 55, Issue 2). http://www.imf.org/external/pubs/ft/fandd/2018/06/pdf/fd0618.pdf

[10] Leadership, T. (n.d.). What the world will look like after the CovID-19 crisis. https://atos.net/content/2020/atos-report-what-the-world-will-look-like-after-the-covid-19-crisis.pdf

[11] Lim, J. W. (2015). A Facilitative Model for Cryptocurrency Regulation in Singapore. Handbook of Digital Currency: Bitcoin, Innovation, Financial Instruments, and Big Data, 361-381. https://doi.org/10.1016/B9780-12-802117-0.00018-7

[12] Maire, B. Le, Landau, E. J., \& Genais, A. (2019). Digital Currencies - An exploration into technology and money. June.

[13] Morabito, V. (2017). Digital Currencies. In Business Innovation Through Blockchain (Issue November). Springer International Publishing. https://doi.org/10.1007/978-3-319-48478-5_5

[14] Nian, L. P., \& Chuen, D. L. K. (2015). Introduction to Bitcoin. Handbook of Digital Currency: Bitcoin, Innovation, Financial Instruments, and Big Data, April, 5-30. https://doi.org/10.1016/B978-0-12-802117-0.00001-1

[15] Perkins, D. W. (2020). Cryptocurrency: The Economics of Money and Selected Policy Issues. 1-30. https://crsreports.congress.gov

[16] Peters, G. W., Panayi, E., \& Chapelle, A. (2015). Trends in Crypto-Currencies and Blockchain Technologies: A Monetary Theory and Regulation Perspective. SSRN Electronic Journal, 3(3). https://doi.org/10.2139/ssrn.2646618 
[17] Rose, C. (2015). The Evolution Of Digital Currencies: Bitcoin, A Cryptocurrency Causing A Monetary Revolution. International Business \& Economics Research Journal (IBER), 14(4), 617. https://doi.org/10.19030/iber.v14i4.9353

[18] Sibilia, P. (2019). The Digitalization of Life. Dialogue and Universalism, 29(3), 93-102. https://doi.org/10.5840/du201929339

[19] The future of money. (2011). New Scientist, 210(2815), 5. https://doi.org/10.1016/S0262-4079(11)612785

[20] Wadsworth, A. (2018). Bulletin - Reserve Bank of New Zealand. 81(3), 1-14. https://www.rbnz.govt.nz/research-and-publications/reserve-bank-bulletin/2018/rbb2018-81-03

[21] Ward, O., \& Rochemont, S. (2019). An addendum to “ A Cashless Society- Benefits, Risks and Issues ( Interim paper )" Understanding Central Bank Digital Currencies ( CBDC ). March. https://www.actuaries.org.uk/system/files/field/document/Understanding CBDCs Final - disc.pdf

\section{WEBSITE LINKS}

[1] https://www.imf.org/en/News/Articles/2019/05/13/sp051419-stablecoins-central-bank-digitalcurrencies-and-cross-border-payments

[2] https://www.imf.org/en/Publications/WP/Issues/2019/03/01/Cash-Use-Across-Countries-and-theDemand-for-Central-Bank-Digital-Currency-46617

[3] https://www.rbnz.govt.nz/research-and-publications/reserve-bank-bulletin/2018/rbb2018-81-03

[4] https://www.bis.org/publ/bppdf/bispap107.pdf

[5] https://en.wikipedia.org/wiki/Digital_currency

[6] https://www.investopedia.com/terms/d/digital-currency.asp

[7] https://www.intechopen.com/books/blockchain-and-cryptocurrencies/blockchain-and-digital-currencyin-the-world-of-finance

[8] https://www.scribd.com/document/401691596/blockchainrev18-e-pdf

[9] https://www.adb.org//

[10] https://www.coinsnews.com/rss/cryptocoins-news/coin-news-asia

[11] https://www.researchgate.net/publication/335351165_Central_bank_Digital_Currencies_Key_Characteristi cs_and_Directions_of_Influence_on_Monetary_and_Credit_and_Payment_Systems

\section{ABOUT THE AUTHOR}

Dr. N. HARIHARAN is the Founder and Director of SHRI ACADEMY, Pune, Maharashtra, India. He is into Academics for more than 25 years serving in various capacities at reputed institutes teaching Core Finance and Business subjects at Undergraduate, Postgraduate and Professional Course levels in India and Abroad. He has attended and presented papers in various national and international conferences. He is also a Visiting Faculty in different B-Schools. He is member, board of studies/examiner in various universities and institutions. He is also member of Editorial Board of various Management Journals published from USA and India. He specializes in the field of Taxation, Accountancy and Finance. He has authored 12 editions of Income Tax Law and Practice and Income Tax Problems and Solutions (Indian Tax System). He has co-

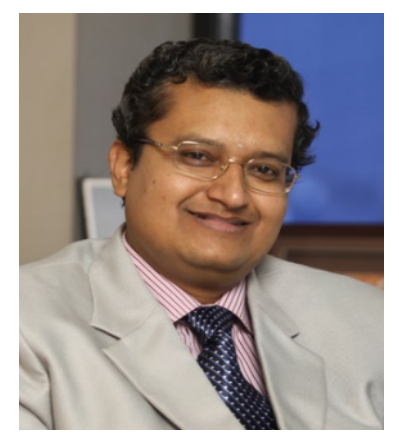
authored 02 books on Cost Accounting. He has guided more than 1000 projects for postgraduate courses for Indian and International Universities. His qualification is approved and recognized by BQA - Botswana Qualifications Authority as equivalent to NCQF Level 10. 